\title{
IMPORTANCE OF BREAK-EVEN ANALYSIS FOR THE MICRO, SMALL AND MEDIUM ENTERPRISES
}

\author{
Lis Sintha Oppusunggu ${ }^{*}$ 四 \\ ${ }^{* 1}$ Universitas Kristen, Indonesia
}

DOI: https://doi.org/10.29121/granthaalayah.v8.i6.2020.502

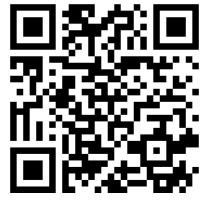

Article Type: Research Article

Article Citation: Lis Sintha Oppusunggu. (2020). IMPORTANCE OF BREAK-EVEN ANALYSIS FOR THE MICRO, SMALL AND MEDIUM ENTERPRISES. International Journal of Research -GRANTHAALAYAH, 8(6), 212-218.

https://doi.org/10.29121/granthaa layah.v8.i6.2020.502

Received Date: 08 May 2020

Accepted Date: 30 June 2020

Keywords:

CVP Analysis

Break-Even Point

Medium Enterprises

\section{ABSTRACT}

The current behaviour of Small and Medium Enterprises has to face many problems and the survey are predicted, 47 per cent of Small and Medium Enterprises stop trying. One of the causes is that there are still many small and medium businesses, from the beginning of opening their business up to now, they have never carried out an analysis of profit and loss calculations and a comprehensive calculation of how many product units should be made so that the business returns on capital by looking at production factors or resources used. Break-even analysis is a financial tool that helps decide at what stage a company, or new service or product, will be profitable, which is a financial calculation to decide the number of products or services that a company must sell to cover its costs (especially fixed costs). This research paper is the application of the theoretical concepts of CVP Analysis, Break-Even Point a powerful tool for planning and decision making. highlight costs, quantities sold and prices, which are the company's financial information.

\section{INTRODUCTION}

In this globalization era, the world economy is experiencing crisis, challenges and obstacles which are quite alarming and felt by several countries. Almost all businesses feel the impact of the coronavirus outbreak, social constraints cause various business activities must be done remotely, so, many workers work from home (work from home). Based on the results of a survey carried out several institutions and the Ministry of Small and Medium Enterprises, Corona outbreaks virus has a big impact on the survival of Small and Medium Enterprises, must now face a pretty big problem and forecast the survey, 47 per cent of Small and Medium Enterprises stop trying [1], [2]. One cause is the Small and Medium Enterprises are constrained on the supply side due to disruption of distribution during a pandemic Covid-19 and the weakness further depress demand-side sustainability of Small and Medium Enterprises in the country [3], [4], [5]. Besides, there are still many small and medium businesses from the beginning of opening their businesses up to now have never done an analysis of profit and loss calculations and a comprehensive calculation of how many product units should be made so that the business returns on capital by looking at production factors or resources used.

To maintain the sustainability of the company's life in the face of economic conditions this requires good managerial management. Management required to coordinate all available resources effectively and efficiently and can make managerial decisions to support the achievement of the company is to maximize profit through the amount

(C) 2020 The Author(s). This is an open access article distributed under the terms of the Creative Commons Attribution License, which permits unrestricted use, distribution, and reproduction in any medium, provided the original author and source are credited. 
Importance of Break-Even Analysis for The Micro, Small and Medium Enterprises

sold, the unit cost and the selling price. Managing the company's profit or loss is very important to accelerate the company's profitability. From income statement, clearly defined the position of finance companies so that managers can reduce unnecessary costs and increase revenue. Break-even point is the point where the company generates an amount of profit equal to the cost of the production process in the accounting period. Because income and expenses are the same, the net profit for the period is zero. Break-even analysis is also a way to find out the minimum sales volume so that a business does not suffer losses, but also has not yet made a profit (in other words the profit is equal to zero). In the break-even point analysis requires information about sales and costs incurred. The concept of break-even point can be applied in all businesses and any industry, whether large or small. This paper provides several financial management strategies based on the theories and findings from previous studies.

\section{LITERATURE REVIEW}

Micro, Small and Medium Enterprises are trading businesses managed by business entities or individuals that refer to productive economic businesses following the criteria stipulated by Law Number 20 the Year 2008. In the Indonesian economy, Micro, Small, and Intermediate is the business group that has the largest number and Small and Medium Enterprises is more resilient to various kinds of economic crisis shocks [8], [9], [10]. The business criteria included in Small and Medium Enterprises have been regulated in a legal umbrella based on the law. Although the business scale targeted by Small and Medium Enterprises businesses is not as large as a large- scale enterprise, many people are comfortable doing business at this level because of the advantages offered to micro and small and medium-sized businesses and these advantages are difficult to obtain at the giant business level [11], [12], [13]. One of the main advantages is the ease of adopting innovation in business, especially in the field of technology. The adoption of the latest technology has become easier to do to increase the growth of Small and Medium Enterprises businesses because it does not have a complicated bureaucracy and complicated systems [14], [15].

In addition to the ease of technology application, excellence in employee relations factors is due to its smaller scope, and the flexibility to adapt the business to dynamic market conditions [16], [17], [18]. To improve the competitiveness of SMEs in Indonesia, Michael Porter state that there are 3 strategies must be carried out, namely: a) Cost leadership - Trying to win the competition by approaching prices, wherewith certain prices for the products it produces consumers are more interested in buying these products; b) Differentiation (Product Unique) - To win the business competition, the company tries to make a unique product, where the product is difficult for the company's competitors to imitate; and c) Focus/Competitive Strategy - This strategy focuses activities on consumers with certain segments. Targeting this particular segment of consumers will make it easier for companies to win the business competition.

Break-even point is a point where the cost or expenses and revenue are balanced so there is no loss or gain [18], [19]. In other words, that is the point where the company has neither profit nor loss. Perform analysis of break-even point is analyzing the tool company managers in the company's production costs. In a simple analysis of the breakeven point can give out the information about whether revenue product can cover the costs relevant $n$ of the product. Management can use this information to make various business decisions, including setting prices, preparing competitive bids, and applying for loans [19], [20], [21]. Likewise, with the managerial concept, the breakeven analysis seeks to find the appropriate amount of output so that no loss is incurred. The manager can determine the minimum amount of sales in which the company does not suffer losses. If a product cannot cover its costs, it will reduce the company's profitability.

Profitability is the goal of every business owner. But before management can make a profit, the company must break even. Many other factors affect the financial health of a company over time, such as projected changes in market conditions. Break-even analysis as a basis can provide an idea of where a business is at a certain point in time, which must be used in conjunction with other financial stages. Break-even analysis can be mem provide important preliminary information about the business status of the company [22], [23], [24]. If the results of the analysis reveal that sales are not enough to cover costs, or that the contribution margin is smaller than they should, management can take action to lower the breakeven point. The pre-market analysis is the main step that needs to be taken before applying breakeven because of its many environmental influences [25], [26], [27]. Zaroni said that Cost-Volume-Profit Analysis (CVP) is a very useful model for planning and management decision making in determining units to be sold to achieve desired profits. CVP analysis illustrates the relationship between units sold, 
costs, selling prices, and profits, which can explain some important issues in management decisions such as the impact of reducing total fixed costs on profits, the impact of policies on increasing product selling prices on profits, and others. Managers can use CVP analysis for sensitivity analysis of several alternative scenarios due to the risk of changes in selling prices, changes in fixed costs, changes in variable costs, and changes in tax rates.

CVP analysis is formulated from the simple concept of profit calculation. Profit is calculated from the reduction between total revenue (total revenue) and total costs (total cost). In the break-even condition, profit is zero, then:

Profit $=$ Total Revenue - Total Cost

Profit $=($ Proce $x$ Quantity $)-$ Variable Cost - Fixed Cost

Profit $=(P \times Q)-(v c \times Q)-F C$

In the break-even condition, profit equals zero, then:

Profit $=(P \times Q)-(v c \times Q)-F C=0$

$(P-v c) Q=F C$

$\mathrm{Q}=\frac{F C}{(P-V C)}$

Note:

$\mathrm{P}=$ Price

$\mathrm{vc}=$ Variable cost per unit

$\mathrm{FC}=$ Fixed cost

The CVP analysis formula above is used to determine how many units should be sold at break-even or profit conditions equal to zero. Unit of measurement of sales units varies greatly, depending on the type and characteristics of the product or service provided by the company.

The operating income method focuses on revenue ratios as a useful tool in managing fixed costs and variable costs. P densities can be expressed as exponential equations:

Operating Income = Sales Revenue - Variable Costs - Fixed Costs.

Specifically, revenue from sales is the selling price per unit, multiplied by the number of units sold. In this term, the operating income for the formula is:

Operating Income = (price $x$ number of units) - (variable cost per unit $x$ number of units) - fixed total costs.

The refinement of the operating income method is the contribution level method. Just pay attention that at the break-even point, the total contribution of the margins is the same to improve expenditure. Contribution margins represent revenue from sales minus total variable costs. If we replace the entity's contribution margin with price, minus the variable unit cost, and we solve it per unit figure, we will get the following equation for profitability:

Number of units $=$ Fixed Cost - Contributions to unit

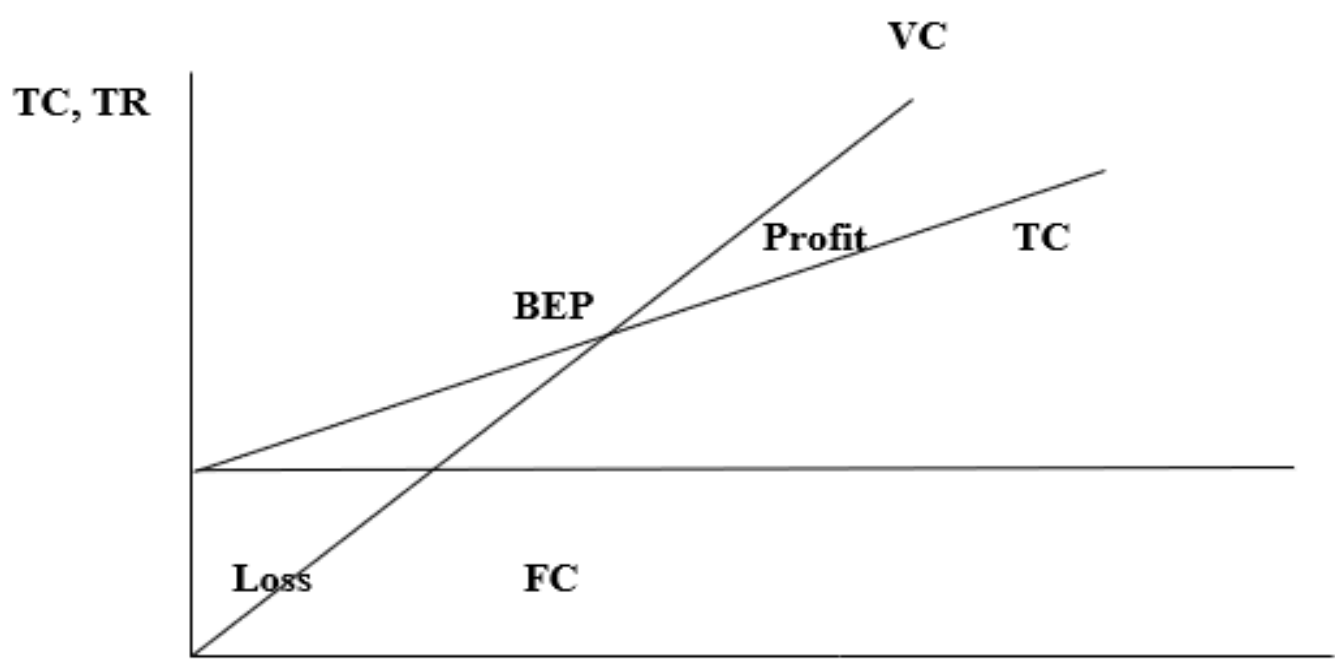

Unit

Figure 1: Break-Even Point 
Importance of Break-Even Analysis for The Micro, Small and Medium Enterprises

\section{Description:}

1) Flat growth (unit) shows sales volume that can be expressed in units of quantity or rupiah sales revenue.

2) The vertical axis ( $Y$ ) shows revenue and cost of sales in rupiah

3) Creating a sales line is as follows: At sales volume equals zero and income equals zero. A straight line is then drawn to connect the points $\mathrm{x}=0$ and $\mathrm{y}=0$.

4) Lane construction is still being done because there are no fixed costs in any sales volume

5) certain capacity changes.

6) The break-even point is located at the point of intersection of the sales revenue line with the coastline

7) The area to the left of the breakeven point, that is the area between the total cost line and

8) the sales revenue line is the area of loss, because sales revenue is lower than the total cost, while the area to the right of the breakeven, the area between sales revenue and total

9) the costs line is the profit area because sales revenue is higher than the total costs.

\section{RESEARCH METHOD}

This research is a literature study, and it was done at Universitas Kristen Indonesia, Jakarta. The instrument of this study is the researcher itself as the key instrument. The research data analysis used is the descriptive technique, were to answer the research problem, the researcher research read the theories which are related to the topic of this research "Importance of Break-Even Analysis For the Micro, Small and Medium Enterprises" sourced from books, journals and proceedings and other previous researches which were analyzed descriptively.

\section{RESULT AND DISCUSSION}

Based on some of the opinions above, it can be concluded that the break-even analysis is a tool used to determine the break-even point of the company where the company does not experience losses and does not get profits. Breakeven analysis can be seen the minimum revenue that must be achieved by the company to get the targeted profit for the following year. Break-even analysis is a financial tool that helps determine at what stage a company, or new service or product, will benefit. In other words, this is a financial calculation to determine the number of products or services that a company must sell to cover its costs (especially fixed costs). Break-even is a situation where the company does not make money or lose money, but all costs have been overcome. Analysis point of breakeven useful in studying the relationship between variable costs, fixed costs and revenues. Generally, companies with low fixed costs will have a break-even point of sale [6], [18], [28].

Starting a new business - If you want to start a new business, break-even analysis is a must. Not only does it help in deciding whether the idea of starting a new one is feasible, but it will make management to be realistic about costs, and determine the pricing strategy [29], [30]. Making new products - In the case of existing businesses, management must continue to break-even analysis before launching new products, especially if such a product will add significant expenditure. Change business model - If you are going to change your business model, for example, switching from a wholesale business to a retail business, you still have to break-even analysis. Costs can change a lot and this will help find out the selling prices that need to be changed too. Uses of Breakeven Analysis: a) Assisting to determine the capacity of the unemployed once the breakeven point is reached. This will help to show the maximum profit in certain products/services that can be produced; b) Assisting to determine the effect on changes the profit due to the fixed costs of replacing the variable costs); c) Assisting to determine the changes in profit if the price of a product is changed, and d) Assisting to determine the amount of loss that can be sustained if there is a decline in sales [31], [32].

Besides, break-even analysis is very useful for knowing the overall business ability to generate profits. The company which approached the breakeven point of maximum sales level, this indicates that it is almost impractical for businesses to profit even under the best of circumstances. Therefore, it is management's responsibility to monitor the breakeven point continuously in several ways, namely by using:

Price analysis - Minimize or eliminate the use of coupons or other price reduction offers, because such promotional strategies increase breakeven; Technology analysis - Implement technology that can improve business efficiency, thereby increasing capacity without additional costs; Cost analysis - Review all fixed costs constantly to verify whether anything can be eliminated and review the total variable costs to see if they can be 
eliminated. This analysis will increase margins and reduce breakeven points; Margin Analysis - Increasing sales of goods with the highest margins (high contribution income) and pay attention to product margins, thereby reducing breakeven points; Outsourcing - If an activity consists of fixed costs, try to outsource such activities (if possible), which reduces the breakeven point [33], [34].

Companies that do an analysis the breakeven point would be (a) Catching spending is lost because k ethical thinking about the new business and all plans of finance will be inspected to determine the breakeven point of his. This analysis certainly limits the amount of unexpected expenditure. (b) set target revenue, it will be known how many products are needed for on-sale to make it profitable. This will help the sales team to set more concrete sales goals. (c) developing smarter decisions, the entrepreneur often makes decisions concerning their business is not based on emotion but a decision that is based on facts. (d) the finance business is a key component in any business plan. Usually, a requirement if the company wants outsiders to fund its business. to get funds from outside the company, the company must be able to prove that the plans of companies feasible (e) the establishment of a better price, by finding the breakeven will assist in determining the price of the products better. This tool is very used to provide the best price of a product that can make a maximum profit without increasing the existing price. (f) cover fixed costs: Performing a break-even analysis helps to cover all fixed costs.

\section{CONCLUSION}

Factors that can affect the level of profit obtained by a company, namely: (1) Total costs incurred to produce products/services that are reflected by the cost of goods sold (2) Number of goods/services produced and sold, and (3) the selling price of the goods concerned so that the company's management must try to control these three things. Thing else that needs to be noticed is that all goods produced can be sold. To determine income, it is assumed that the goods produced are sold out entirely. In the factors that affect the level of profit, management can reduce costs to the minimum cost level. On the other hand, the sales volume of goods/services can be increased to the maximum level, so that the goods produced are sold out. Determination of the selling price is determined by achieving an adequate level of profit per unit so that the selling price can be reached by the public-consumer. The effort of the company/management to look for profit must be based on how many items must be produced and then sold. In the production planning stage, company management must determine in advance the minimum production level so that the company does not lose. In other words, the initial stage of production planning must be based on efforts not to lose or break even. The purpose of breakeven is the company's total revenue (total revenue) is equal to the total costs incurred (TR -TC).

\section{SOURCES OF FUNDING}

None.

\section{CONFLICT OF INTEREST}

None.

\section{ACKNOWLEDGMENT}

None.

\section{REFERENCES}

[1] Bartik, A. W., Bertrand, M., Cullen, Z. B., Glaeser, E. L., Luca, M., \& Stanton, C. T. (2020). How are small businesses adjusting to COVID-19? early evidence from a survey (No. w26989). National Bureau of Economic Research.

[2] Velavan, T. P., \& Meyer, C. G. (2020). The COVID-19 epidemic. Tropical medicine \& international health, 25(3), 278. 
Importance of Break-Even Analysis for The Micro, Small and Medium Enterprises

[3] Nicola, M., Alsafi, Z., Sohrabi, C., Kerwan, A., Al-Jabir, A., Iosifidis, C., ... \& Agha, R. (2020). The socio-economic implications of the coronavirus and COVID-19 pandemic: a review. International Journal of Surgery.

[4] Ozili, P. K., \& Arun, T. (2020). Spillover of COVID-19: Impact on the Global Economy. Available at SSRN 3562570 .

[5] Loayza, N. V., \& Pennings, S. (2020). Macroeconomic policy in the time of COVID-19: A primer for developing countries.

[6] Rambo, C. M. (2013). Time Required to Break-Even for Small and Medium Enterprises: Evidence from Kenya. International Journal of Management and Marketing Research, 6(1), 81-94.

[7] Wolmarans, H. P., \& Meintjes, Q. (2015). Financial management practices in successful Small and Medium Enterprises (SMEs). The southern African journal of entrepreneurship and small business management, 7(1), 88-116.

[8] Mbogo, M. (2011). Influence of Managerial Accounting Skills on SME's on the Success and Growth of Small and Medium Enterprises in Kenya. Journal of Language, Technology \& Entrepreneurship in Africa, 3(1), 109-132.

[9] Hanggraeni, D., Ślusarczyk, B., Sulung, L. A. K., \& Subroto, A. (2019). The Impact of Internal, External and Enterprise Risk Management on the Performance of Micro, Small and Medium Enterprises. Sustainability, 11(7), 2172.

[10] Tyas, E. H., \& Naibaho, L. (2019, November). The urgency of entrepreneurship learning in the industrial age of 4.0. In Journal of Physics: Conference Series (Vol. 1387, No. 1, p. 012032). IOP Publishing.

[11] Cvetkoska, V. (2016). A survey of the use of operational research in decisions made by micro, small and medium-sized enterprises in Macedonia. Croatian Operational Research Review, 349-365.

[12] Wiechetek, Ł. (2012). The conception of a time break-even point in information systems implementation in small and medium-sized enterprises. organizacja I ZARZĄDZANIE, 161.

[13] Tyas, E. H., \& Sunarto, L. N. (2020). Building Superior Human Resources through Character Education.

[14] Hussain, A. S. M., \& Jalal, A. B. M. (2015). Micro-Factors Influencing Site Selection for Small and Medium Enterprises (SMEs) in Saudi Arabia: Al-Hassa area using Analytical Hierarchy Process (AHP) Analysis. European Scientific Journal, 11, 115.

[15] Eneh, O. C. (2009). Developing a holistic marketing approach for micro, small and medium enterprises (MSME) in Nigeria. Sustainable Human Development Review, 1(3), 25-50.

[16] Brave, S. A., \& Butters, R. (2011). Monitoring financial stability: A financial conditions index approach. Economic Perspectives, 35(1), 22.

[17] Naibaho, L. (2019). The Effectiveness of Number Head Together Strategy on Improving Students'english Achievement at XYZ School. International Journal of Research-Granthaalayah, 7(10), 362-370.

[18] Sintha, L. (2019). Bankruptcy Prediction Model of Banks in Indonesia Based on Capital Adequacy Ratio. Journal of Finance and Banking Review, 4(1), 8-16.

[19] Batkovskiy, A. M., Semenova, E. G., Trofimets, V. Y., Trofimets, E. N., \& Fomina, A. V. (2017). Statistical simulation of the break-even point in the margin analysis of the company. Journal of Applied Economic Sciences, Romania: European Research Centre of Managerial Studies in Business Administration, 12(2), 558.

[20] Constandache, N. (2011). The Break-Even Point and the Leverage Effect-Instruments for Assessing the Economic and Financial Risk. Acta Universitatis Danubius. OEconomica, 7(6), 20-33.

[21] Březinová, M. (2013). Representative indicators in process management monitored by small and mediumsized business in the south bohemian region. Finance a výkonnost firm ve věde, výuce a praxis.

[22] Laitinen, E. K. (2011). Extension of break-even analysis for payment default prediction: evidence from small firms. Investment management and financial innovations, (8, Iss. 4), 96-108.

[23] Nadeak, B., \& Naibaho, L. (2019). Managing Lecturers' Competence Development at Universitas Kristen Indonesia.

[24] Sharma, K. D., Pathania, M. S., \& Lal, H. (2010). Value chain analysis and financial viability of agro-processing industries in Himachal Pradesh. Agricultural Economics Research Review, 23(347-2016-16944), 515-522.

[25] Nadeak, B., \& Naibaho, L. (2020). The Effectiveness of Mastery Learning Technique on Improving Students'ability in Completing English National Examination. International Journal of ResearchGranthaalayah, 8(2), 57-62.

[26] Onyango, L. (2018). An analysis of the effect of crowdfunding platforms in enhancing the financing sources for micro, small and medium enterprises (MSMEs) in Kenya (Doctoral dissertation, Strathmore University). 
[27] Sintha, L., Primiana, I., \& Rahman, N. S. (2016). Bank health analysis based on risk profile, earnings and capital. Актуальні проблеми економіки, (7), 386-395.

[28] Adamu, Y. (2018). Impact of Micro, Small and Medium Enterprises (Msmes) on Economic Growth In Nigeria: 1999-2017. JOS, 181.

[29] Rola-Rubzen, M. F., Gibbs, J., Gabunada, F., Burritt, R., Altangerel, D., Rubzen, B., ... \& Carter, A. (2011). Growing businesses in the desert: Case studies of Australian desert micro, small and medium enterprises.

[30] Sintha, L. (2019). Model Earning Dalam Prediksi Kepailitan Bank. Journal of Banking and Finance, 1(1), 1-9.

[31] Niu, E., Saediman, H., \& Surni, S. (2016). Break-Even Analysis of Poultry Egg Production in Rural Area in Southeast Sulawesi. Binus Business Review, 7(3), 227-232.

[32] Joubert, P. (2004, June). Constraints and challenges of small and medium enterprises (SMEs') in Swaziland: a case analysis. In International Council for Small Business: 49th World Conference, Johannesburg, South Africa, June (pp. 20-23).

[33] Naibaho, L. (2019). The Integration of Group Discussion Method Using Audio-Visual Learning Media Toward Students'learning Achievement on Listening. International Journal of Research-Granthaalayah, 7(8), 438-445.

[34] Tahir, F. A., \& Inuwa, F. U. (2019). An empirical investigation of the factors affecting micro, small and medium scale enterprises performance in Borno State, Nigeria. International Business Research, 12(4), 30-39.

[35] Sintha, L. (2018). Financial Performance Banking Model in Indonesia Before and After Implementation of PBI No. 13/1/PBI/2011: Risk Profile Bank Regional Development. KnE Social Sciences, 937-951. 